\title{
RESPONSE OF SUMMER ANNUAL FLOWERING PLANTS TO CHEMICAL, ORGANIC AND BIO-FERTILIZATION TREATMENTS I- JOSEPH'S COAT (Amaranthus tricolor L.) PLANTS
}

\section{E.I. El-Maadawy}

Ornamental Horticulture Department, Faculty of Agriculture, Cairo University, Egypt.

\section{ABSTRACT}

This study was carried out at the Experimental Nursery of the Ornamental Horticulture Department, Faculty of Agriculture, Cairo University, Giza, during the two successive seasons of 2000 and 2001, with the aim of investigating the effect of chemical, organic and bio-fertilization treatments on the growth and chemical composition of Joseph's coat (Amaranthus tricolor L.) plants.

The treatments included fertilization with $P K(P$ at $6 \mathrm{~g}$ calcium superphosphate, and $K$ at $3 \mathrm{~g}$ potassium sulphate / 25-cm clay pot), combined with: (1) $N$ fertilization at the rates of 6 or $12 \mathrm{~g}$ ammonium sulphate /pot ( $N_{1}$ and $N_{2}$, respectively), (2) Bio-fertilization (Bio), (3) Bio. + half the previous $N$ fertilization rates $\left(1 / 2 N_{1}\right.$ or $\left.N_{1}\right)$, (4) Cattle manure (CM) at the rate of $710 \mathrm{~cm}^{3} /$ pot (equivalent to $40 \mathrm{~m}^{3} /$ feddan), or (5) Bio + CM at $355 \mathrm{~cm}^{3} /$ pot (equivalent to $20 \mathrm{~m}^{3} /$ feddan). Control plants received $P K$ fertilization only. The bio-fertilizer was applied to the soil as a liquid inoculum containing Azospirillum brasilense, Klebsiella pneumonia and Pseudomonas putida. Most of the fertilization treatments increased the different vegetative growth and flowering characteristics. Among the different treatments, combining Bio with CM (i.e. $P K+$ Bio $+1 / 2 C M$ ) was the most effective one, giving the highest values for plant height, stem diameter, leaf area, number of flower stalks/plant, fresh and dry weights of leaves and stems/plant, as well as the the highest contents of chlorophyll " $a$ ", total chlorophylls $(a+b)$, carotenoids and anthocyanin in the leaves. Also, this treatment $(P K+$ Bio $+1 / 2 C M)$ gave the highest content of total carbohydrates in the leaves, stems, flowers and roots (in most cases). On the other hand, $\mathrm{PK}+\mathrm{N}_{2}$ gave the highest numbers of branches /plant, and the longest flowering stalks, while the highest number of leaves was found on plants fertilized using $P K+N_{2}$ or $P K+1 / 2 C M+$ bio-fertilization. $P K+N_{1}$ + Bio gave the highest roots fresh weight in both seasons. Plants fertilized with $P K+N_{2}$ had the highest $N$ content in the leaves (in both seasons), stems and flowers (in the first season), as well as the highest $P$ content in the roots (in both seasons) and stems (in the second season).

It was concluded that, for best vegetative growth and flowering of Amaranthus tricolor, L. the plants should be fertilized using the previously 
described mixture of $P K$, bio-fertilization and half of the full dose of organic (cattle) manure.

Key words: Summer annual flowering plants, chemical, organic, biofertilization treatments, joseph's coat, Amaranthus tricolor L. plants.

\section{INTRODUCTION}

Joseph's coat (Amaranthus tricolor L.) is an annual plant belonging to the Amaranthaceae family. It is one of 14 Amaranthus species that grow in Egypt. In addition to its use as a landscape plant, it is used in China as a medicinal plant to improve vision and to strengthen the liver. Also, its ash is mixed with rapeseed oil, and used in the manufacture of an ointment applied externally as a dressing for broils and itching (Hu, 1959). The use of A. tricolor L.plants as a source of natural pigments used for colouring foods, beverages and bread products has been recognized by several scientists [Cai, et. al. (1998), and Lehmann (1990)]. The Amaranthus genus contains species and genotypes that can be used as high quality multipurpose highpotential crops for modern agriculture, for food, feed, and forage uses, and also as an ornamental plant because of its rich colourful leaves, inflorescences, stems and seeds (Paredes-Lopez, 1994). Leaves and grains are used for food in parts of South and Central America, Africa and Asia. Amaranth plants are high in protein, and their amino acid composition is complementary to that of wheat.

As in all other horticultural crops, fertilization is one of the main factors affecting growth and productivity of Amaranthus tricolor plants. For many years, there has been an increasing demand for the use of organic manures and bio-fertilizers as alternatives to conventional chemical fertilization. The use of these types of fertilizers alleviates the dangers of using chemical fertilizers, including aquifer pollution, and chemical residues in plant tissues that are consumed by humans. In addition to helping in the production of safe organically- grown horticultural products, application of organic manures is also known to improve several soil characteristics, including its water holding capacity, resistance to compaction, and cation exchange capacity. This makes it feasible to use these fertilizers in newly reclaimed desert areas where the poor sandy soil may not be suitable for growing economically important horticultural crops. Furthermore, the substitution of chemical fertilization, at least partly, with organic manures or bio-fertilizers may result in a reduction of production costs. The effect of organic manures on the growth and productivity of ornamental and medicinal plants has been investigated by several researchers (Mohamed, 2003) on Catharanthus roseus, Sakr (2005) on Cassia acutifolia, and many others]. Also, the use of biofertilizers, with or withour chemical or organic fertilizers, has been studied by many workers [Abdou and El-Sayed (2002) on Carum carvi, and Hafez (2003) on Borago officinalis].

This study was conducted with the aim of investigating the effect of chemical, organic and bio-ferilization treatments on the growth, flowering and chemical composition of Amaranthus tricolor L. plants. 


\section{MATERIALS AND METHODS}

This study was carried out at the Experimental Nursery of the Ornamental Horticulture Department, Faculty of Agriculture, Cairo University, Giza, during the two successive seasons of 2000 and 2001, with the aim of investigating the effect of chemical, organic and bio-ferilization treatments on the growth and chemical composition of Amaranthus tricolor L. plants.

Seeds of of Amaranthus tricolor L. were obtained from the Nursery of the Ornamental Horticulture Department. On April 1 $1^{\text {st }}, 2000$ and 2001 seasons, the seeds were sown in well-prepared seed beds with a loamy clay soil and peatmoss. On $15^{\text {th }}$ May 2000 and 2001 seasons, the seedlings, with a height of 5-7 cm, were transplanted into $25-\mathrm{cm}$ clay pots filled with a sandy soil. The chemical characteristics of the potting sandy soil are shown in Table (A).

The pots received different chemical, organic and bio-fertilization treatments which included the application of phosphorus and potassium (PK) fertilization, combined with: (1) Nitrogenous fertilization at the rates of 6 or $12 \mathrm{~g}$ ammonium sulphate /pot, (2) Bio-fertilization, (3) Bio-fertilization $+\mathrm{N}$ fertilization at 3 or $6 \mathrm{~g}$ ammonium sulphate/pot/season, (4) Cattle manure at the rate of $710 \mathrm{~cm}^{3} / \mathrm{pot}$ (equivalent to $40 \mathrm{~m}^{3} /$ feddan), or (5) Cattle manure at $355 \mathrm{~cm}^{3} /$ pot (equivalent to 20 $\mathrm{m}^{3} /$ feddan) + bio-fertilization. Control plants received PK fertilization only.

Phosphorus fertilization was added to all plants in the form of calcium superphosphate $\left(15.5 \% \quad \mathrm{P}_{2} \mathrm{O}_{5}\right)$, which was mixed into the soil two weeks before planting the seedlings, at the rate of $6 \mathrm{~g} /$ pot. On the other hand, potassium fertilization was added in the form of potassium sulphate $\left(48 \% \mathrm{~K}_{2} \mathrm{O}\right)$ at the rate of $3 \mathrm{~g}$ /pot, divided into two equal doses, which were applied after 2 and 4 weeks from planting. Plants receiving $\mathrm{N}$ fertilization were supplied with the above-mentioned rates of ammonium sulphate $(20.5 \% \mathrm{~N})$, divided into 3 equal doses applied at 3 -week intervals, starting two weeks after transplanting. Plants receiving bio-fertilization were supplied with a composite inoculum (containing Azospirillum brasilense, Klebsiella pneumonia and Pseudomonas putida) in the form of a liquid culture, which was applied at the time of planting at the rate of $10 \mathrm{ml} /$ pot. An additional dose of 10 $\mathrm{ml} /$ pot of the liquid culture was applied one month after planting (on $15^{\text {th }}$ June 2000 and 2001, seasons. The bacterial count of the composite inoculum (as described by Hegazi et al., 1998) is shown by the data in Table (B). In plants receiving cattle manure (CM) treatments, the tested rates (40 or $20 \mathrm{~m}^{3} /$ feddan) were added to the soil 15 days before planting. The physical and chemical characteristics of the cattle manure used in this experiment are shown in Table (C).

The layout of the experiment was a randomized complete blocks design, with 8 treatments (including the control) and 3 blocks (replicates), each consisting of 5 pots / treatment.

At the termination of each season, on the $1^{\text {st }}$ of October, 2000 and 2001. data were recorded on plant vegetative growth characterisctics, including plant height $(\mathrm{cm})$, stem diameter $(\mathrm{cm})$ at a height of $5 \mathrm{~cm}$ from the soil surface, number of branches /plant, number of leaves /plant, leaf area $\left(\mathrm{cm}^{2}\right)$ of the $4^{\text {th }}$ leaf from the top of 
Table A. Chemical characteristics of the sandy soil used for potting Amaranthus tricolor $\mathrm{L}$. plants in the 2000 and 2001 seasons.

\begin{tabular}{|c|c|c|c|c|c|c|c|c|c|c|c|c|c|c|c|c|c|}
\hline \multirow[t]{2}{*}{ 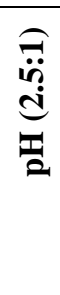 } & \multirow{2}{*}{ 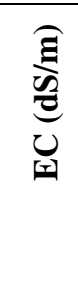 } & \multirow{2}{*}{ 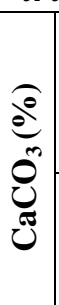 } & \multicolumn{4}{|c|}{$\begin{array}{l}\text { Soluble cations } \\
\quad(\mathrm{meq} / \mathrm{L})\end{array}$} & \multicolumn{4}{|c|}{$\begin{array}{l}\text { Soluble anions } \\
\quad(\mathrm{meq} / \mathrm{L})\end{array}$} & \multicolumn{3}{|c|}{$\begin{array}{c}\text { Macro- } \\
\text { nutrients } \\
\text { content } \\
\text { (ppm) }\end{array}$} & \multicolumn{4}{|c|}{$\begin{array}{l}\text { Micro-nutrients } \\
\text { content (ppm) }\end{array}$} \\
\hline & & & שֶ & $\sum_{\sum}^{+\infty}$ & ${ }^{+\pi}$ & 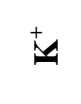 & ల & $\overbrace{0}^{\infty}$ & $\bar{\tau}$ & రి & $\mathbf{N}$ & $\mathbf{P}$ & $\mathbf{K}$ & $\mathbf{F e}$ & $\mathbf{C u}$ & $\mathbf{Z n}$ & Mn \\
\hline 8.7 & 2.88 & 0.4 & 7.2 & 2.2 & 19 & 0.37 & -- & 1 & 13.5 & 14.27 & 57 & 12 & 96 & 0.62 & 0.16 & 0.24 & 0.28 \\
\hline
\end{tabular}

Table B. The bacterial count of the composite inoculums used for biofertilization of Amaranthus tricolor L. plants in the 2000 and 2001 seasons.

\begin{tabular}{|l|c|c|}
\hline Bacteria & Log No. $\mathbf{~ l l}^{-1}$ & Log No. sed $^{-1}$ \\
\hline Total bacterial count & 7.56 & 6.08 \\
Azospirillum brasilense & 6.96 & 5.48 \\
Pseudomonas putida & 7.40 & 5.92 \\
Klebsiella pneumonia & 7.00 & 5.52 \\
\hline
\end{tabular}

Table C. Physical and chemical characteristics of the cattle manure used for fertilization of Amaranthus tricolor L. plants in the 2000 and 2001 seasons.

\begin{tabular}{|c|c|c|c|c|c|c|c|c|c|c|c|c|c|c|c|c|c|}
\hline \multirow{2}{*}{ } & \multirow{2}{*}{ 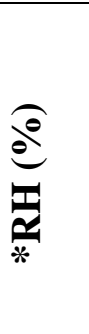 } & \multirow{2}{*}{$\begin{array}{l}\underbrace{20}_{0} \\
\sum_{0}^{*} \\
*\end{array}$} & \multirow{2}{*}{ 졸 } & \multirow{2}{*}{ 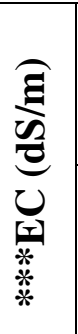 } & \multicolumn{4}{|c|}{$\begin{array}{c}\text { Soluble cations } \\
\quad(\mathrm{meq} / \mathrm{L})\end{array}$} & \multicolumn{3}{|c|}{$\begin{array}{l}\text { Soluble anions } \\
\quad(\mathrm{meq} / \mathrm{L})\end{array}$} & \multicolumn{3}{|c|}{$\begin{array}{c}\text { Macro- } \\
\text { nutrients } \\
\text { content }(\%)\end{array}$} & \multicolumn{3}{|c|}{$\begin{array}{c}\text { Micro- } \\
\text { nutrients } \\
\text { content } \\
\text { (ppm) }\end{array}$} \\
\hline & & & & & שָ & $\sum_{\infty}^{+\infty}$ & + & \pm & $\rho^{m}$ & $\bar{v}$ & రి & $\mathbf{N}$ & $\mathbf{P}$ & $\mathbf{K}$ & $\mathbf{F e}$ & $\mathbf{C u}$ & $\mathbf{Z n}$ \\
\hline$\overline{0.43}$ & \begin{tabular}{|l|l}
10.30 \\
\end{tabular} & 43.00 & 7.80 & 15.60 & 44.80 & 19.40 & $\overline{123.50}$ & 3.60 & 3.80 & 120.30 & 67.20 & \begin{tabular}{|l|}
0.90 \\
\end{tabular} & 0.50 & 0.90 & 600 & $\overline{0.00}$ & \begin{tabular}{|l|}
48.0 \\
\end{tabular} \\
\hline
\end{tabular}


the plant (using a Licor portable area meter, model LI 3000), as well as the fresh and dry weights of leaves, stems and roots/plant. Also, data were recorded on the flowering characteristics, including number of flower stalks /plant, stalk length, as well as the fresh and dry weights of flower stalks /plant. The data recorded on vegetative growth and flowering were statistically analyzed. An analysis of variance (ANOVA) was carried out, and the means were compared using the "Least Significant Difference (LSD)" test at the 0.05 level, as described by Steel and Torrie (1980).

Chemical analysis of fresh leaf samples was also conducted to determine their contents of pigments [chlorophyll "a", chlorophyll "b", total chlorophylls $(a+b)$ and carotenoids], using the method described by Saric et al. (1967). In addition, samples of leaves, stems, roots and flowers were oven-dried at a temperature of $70^{\circ} \mathrm{C}$ for 24 hours, and their content of total carbohydrates was determined using the method outlined by Dubois et al. (1956). Also, the nutrients were extracted from dried tissue samples ( leaves, stems, roots and flowers) using the method described by Piper (1947), then the nutrient extracts were chemically analyzed to determine the contents of nitrogen (using a modified Micro-Kjeldahl apparatus, as described by Pregl, 1945), phosphorus (using the method described by Jackson (1967), and potassium [using, flame-photometer (Philips, model PU 9100X), as recommended by Chapman and Pratt (1961)].

\section{RESULTS AND DISCUSSION}

\section{Vegetative growth \\ 1. Plant height}

The results recorded in the two seasons (Table 1) show that most of the fertilization treatments caused significant increases in plants height, compared to the control plants. In both seasons, all treatments that included the application of chemical nitrogenous fertilization or organic (cattle) manure increased plant height significantly, compared to the control. On the other hand, the only treatment that had only a slight (insignificant) effect on plant height was the application of $\mathrm{PK}+$ biofrtilization only. The general increase in plant height as a result of the different fertilization treatments is in agreement with the findings of Dahiya et al. (1998) on African marigold (Tagetes erecta),. This increase in plant height may be a result of both the greater number of cells formed and an increased elongation of the individual cells, Marschner (1999).

When bio-fertilization was combined with chemical $\mathrm{N}$ fertilization $(\mathrm{PK}+1 / 2$ $\mathrm{N}_{1}+$ bio-fertilization or $\mathrm{PK}+\mathrm{N}_{1}+$ bio-fertilization), plant height was significantly increased (compared to plants receiving PK + bio-fertilization only). However, the values recorded when bio-fertilization was combined with chemical $\mathrm{N}$ fertilization were not significantly higher (and were even lower in most cases) than those obtained from plants fertilized with $\mathrm{PK}+\mathrm{N}_{1}$ or $\mathrm{PK}+\mathrm{N}_{2}$ (with no biofertilization). This indicates that there was no advantage (in terms of increasing plant height) for mixing $\mathrm{N}$ fertilization with bio-fertilization, compared to using $\mathrm{N}$ fertilization alone. A similar conclusion was reached by Sakr (2005) on Cassia acutifolia Delile plants. 
In contrast, the results in Table 1 show that in general, mixing bio-fertilization with the application of cattle manure (PK $+1 / 2 \mathrm{CM}+$ bio-fertilization) gave the best results in both seasons. In most cases (especially in the first season), plants receiving this treatment were significantly taller than those fertilized with $\mathrm{PK}+$ bio-fertilization or PK + CM (i.e., when bio-fertilization and cattle manure were used separately). These results indicate that organic fertilization may be essential for the action of the bacteria used in bio-fertilization, and that bio-fertilizers can be used to reduce the need for organic fertilization by half. Similar results have been reported by Sakr (2005) on Cassia acutifolia Delile plants.

\section{Stem diameter}

The data presented in Table 1 show that in most cases, plants receiving the different fertilization treatments had thicker stems than the control plants. The only exception to this general trend was recorded in the second season, with plants fertilized using PK+bio-fertilization having insignificantly thinner stems than the control plants. The favourable effect of the fertilization treatments was generally clearer in the first season, with most of the treatments causing significant increases in stem diameter. On the other hand, only two treatments $\left(\mathrm{PK}+\mathrm{N}_{2}\right.$ and $\mathrm{PK}+1 / 2 \mathrm{CM}+$ biofertilization) increased stem diameter significantly in the second season, compared to the control. The general increase in stem diameter as a result of application of the fertilization treatments is in agreement with the findings of Chandrikapure et al. (1999) on marigold.

The results presented in Table 1 also show that among the different treatments, the least effective one (in terms of increasing stem diameter) was PK+bio-fertilization only. On the other hand, combining bio-fertilization with chemical or organic fertilization gave significantly thicker stems than those obtained when bio-fertilization was used alone.

Also, the recorded data show that, although chemical $\mathrm{N}$ fertilization gave higher values when applied at the high rate $\left(\mathrm{PK}+\mathrm{N}_{2}\right)$ than at the low rate $\left(\mathrm{PK}+\mathrm{N}_{1}\right)$, the difference between the stem diameters recorded with the two rates were insignificant. Moreover, when chemical $\mathrm{N}$ fertilization was combined with bio-fertilization, the recorded values were slightly (insignificantly) lower than those obtained from plants receiving $\mathrm{N}$ fertilization only. This clearly indicates that, although there was no advantage (in terms of stem thickness) for combining chemical $\mathrm{N}$ fertilization and bio-fertilization, compared to using chemical $\mathrm{N}$ fertilization alone, yet it can be concluded that substituting half of the $\mathrm{N}$ fertilization rates with bio-fertilizers may be more economical, since it did not cause a significant reduction in stem thickness.

On the other hand, combining organic fertilization (using cattle manure) with bio-fertlization gave higher values than those obtained in plants supplied with $\mathrm{CM}$ without bio-fertilization. In fact, plants fertilized with $\mathrm{PK}+1 / 2 \mathrm{CM}+$ bio-fertilization gave the highest stem diameters recorded in both seasons. The favourable effect of this treatment was more pronounced in the second season, with plants fertilized using $\mathrm{PK}+1 / 2 \mathrm{CM}+$ bio-fertilization having significantly thicker stems than those receiving most of the other fertilization treatments. 


\section{Number of branches /plant}

The data in Table 1 show that branching of Amaranthus tricolor L. Plants were significantly affected by the different fertilization treatments. In both seasons, most treatments significantly increased the number of branches/plant, compared to the control plants. This promotion of branching as a result of the different fertilization treatments is in agreement with results reported Dahiya et al. (1998) on (Tagetes erecta), and Sakr (2005) on Cassia acutifolia Delile plants plants.

Among the different treatments, plants fertilized with $\mathrm{PK}+\mathrm{N}_{2}$ gave the highest numbers of branches in both seasons. The favourable effect of this treatment was more pronounced in the first season than in the second, with plants fertilized using $\mathrm{PK}+\mathrm{N}_{2}$ giving a significantly higher number of branches in the first season, compared to plants supplied with most of the other treatments. Substituting part (half) of the chemical $\mathrm{N}$ fertilization treatment with bio-fertilization (i.e. supplying the plants with $\mathrm{PK}+1 / 2 \mathrm{~N}_{1}+$ bio-fertilization instead of $\mathrm{PK}+\mathrm{N}_{1}$, or $\mathrm{PK}+\mathrm{N}_{1}+$ bio-fertilization instead of $\mathrm{PK}+\mathrm{N}_{2}$ ) slightly reduced the number of branches/plant.

The results presented in Table 1, also show that using bio-fertilization without chemical $\mathrm{N}$ or organic manure (PK+ bio-fertilization only) was the least effective treatment for increasing the number of branches, as it gave insignificantly higher values than the control (in both seasons).

\section{Number of leaves /plant}

It can be seen from the data in Table 1 that the formation of leaves was significantly promoted by most of the tested fertilization treatments. Only one treatment (PK + bio-fertilization) gave a number of leaves that was significantly lower than that of control plants in the second season.

In both seasons, raising the rate of chemical $\mathrm{N}$ fertilization (with or without biofertilization) caused significant increases in the number of leaves/plant. However, substituting half of the chemical $\mathrm{N}$ fertilization rates with biofertilizers caused significant decreases in the number of leaves/plant, compared to using chemical $\mathrm{N}$ fertilization alone. On the other hand, when cattle manure (CM) was used for fertilization of Amaranthus tricolor plants, replacing half of the $\mathrm{CM}$ with bio-fertilization (i.e., using PK $+1 / 2 \mathrm{CM}+$ biofertilization instead of $\mathrm{PK}+\mathrm{CM}$ ) caused a significant increase in the number of leaves/plant (in both seasons). The favourable effect of mixing bio-fertilization with organic manure is in agreement with the findings of Sakr (2005) on Cassia acutifolia Delile plants.

In the first season, the highest number of leaves was obtained on plants fertilized with $\mathrm{PK}+\mathrm{N}_{2}$, followed by plants fertilized with $\mathrm{PK}+1 / 2 \mathrm{CM}+$ biofertilization. In the second season, the same two treatments gave the highest numbers of leaves/plant, but their order was reversed, i.e. plants fertilized with $\mathrm{PK}+1 / 2 \mathrm{CM}+$ bio-fertilization had the highest number of leaves, followed by plants fertilized with $\mathrm{PK}+\mathrm{N}_{2}$. 


\section{Leaf area}

The results recorded in the two seasons (Table 1) show that in most cases, leaf area was not significantly affected (compared to the control) when the plants were supplied with chemical $\mathrm{N}$ fertilization (with or without bio-fertilization), or with bio-fertilization alone. The only exception to this general trend was recorded in the first season, with plants fertilized using $\mathrm{PK}+\mathrm{N}_{1}$ giving significantly larger leaves than the control. A similar increase in leaf area of Amaranthus tricolor as a result of $\mathrm{N}$ fertilization was reported by Nawawi et al. (1986).

On the other hand, leaf area showed a significant increase (compared to the control) when the plants were supplied with organic fertilization (CM). Moreover, this increase in leaf area was more pronounced when $\mathrm{CM}$ was combined with biofertilization. In fact, plants fertilized with $\mathrm{PK}+1 / 2 \mathrm{CM}+$ bio-fertilization gave the largest leaves in both seasons.

\section{Fresh and dry weights of leaves /plant}

The data in Table 2 show that most of the tested fertilization treatments significantly increased the fresh and dry weights of leaves /plant, compared to the control. Supplying the plants with PK + bio-fertilization was the only treatment which never had any significant effect on the fresh or dry weights of leaves (in both seasons). In addition, results recorded in the first season showed that the dry weight of leaves was not significantly affected by fertilization using PK $+\mathrm{CM}$, while in the second season, it was not significantly affected by fertilization using $\mathrm{PK}+\mathrm{N}_{1}$ or $\mathrm{PK}+$ $1 / 2 \mathrm{~N}_{1}+$ bio-fertilization.

It is also clear from the data in Table 2 that, in general, using combinations of bio-fertilization and chemical $\mathrm{N}$ fertilization, or bio-fertilization and cattle manure (CM), were more effective than using $\mathrm{N}$ fertilization or $\mathrm{CM}$ alone. The data also show that when half the rates of chemical $\mathrm{N}$ fertilization or $\mathrm{CM}$ were replaced by bio-fertilization, the fresh and dry weights of leaves /plant were increased considerably. These findings clearly indicate that bio-fertilizers can be used effectively as a partial substitute for traditional chemical and organic fertilizers. This would reduce the yield production cost, and minimize the pollution of the agricultural environment. The beneficial effectof combining mineral $\mathrm{N}$ and bio-fertilizers was also reported by Mahfouz (2003) on Majorana hortensis, and Sakr (2005) on Cassia acutifolia, while the promotive effect of combining organic manures and biofertilizers has ben detected by Mohamed (2003) on periwinkle.

Among the different treatments that were tested, application of $\mathrm{PK}+1 / 2 \mathrm{CM}+$ bio-fertilization gave the highest fresh and dry weights of leaves /plant, whereas the least effective treatment (i.e., giving the lowest values) was $\mathrm{PK}+$ bio-fertilization.

\section{Fresh and dry weights of stems /plant}

The data presented in Table 2 show that most of the fertilization treatments significantly increased the fresh and dry weight of stems /plant in both seasons, compared to the control plants. The only treatment that had no significant effect on the fresh and dry weights of stems /plant was the application of PK + bio-fertilization. 
Table 2. Effect of chemical (NPK), organic and bio-fertilization on the fresh and dry weights (g /plant) of leaves, stems and roots of Amaranthus tricolor L. plants during the 2000and 2001seasons.

\begin{tabular}{|c|c|c|c|c|}
\hline \multirow{2}{*}{ Treatments } & \multicolumn{2}{|c|}{ Fresh weight } & \multicolumn{2}{|c|}{ Dry weight } \\
\hline & 2000 & 2001 & 2000 & 2001 \\
\hline & \multicolumn{4}{|c|}{ Leaves } \\
\hline Control (PK) & 8.44 & 13.25 & 1.24 & 2.15 \\
\hline $\mathbf{N}_{1}$ & 36.79 & 38.57 & 7.97 & 6.64 \\
\hline $\mathbf{N}_{2}$ & 35.72 & 37.31 & 7.21 & 9.70 \\
\hline Bio & 11.32 & 15.76 & 2.17 & 1.91 \\
\hline $1 / 2 \mathbf{N}_{1}+\mathbf{B i o}$ & 54.78 & 52.08 & 10.75 & 8.28 \\
\hline $\mathrm{N}_{1}+\mathrm{Bio}$ & 70.73 & 72.23 & 15.17 & 14.80 \\
\hline CM & 24.62 & 60.40 & 4.93 & 12.09 \\
\hline $1 / 2 \mathbf{C M}+\mathbf{B i o}$ & 72.81 & 86.13 & 16.27 & 30.98 \\
\hline \multirow[t]{2}{*}{\begin{tabular}{|l} 
LSD (0.05) \\
\end{tabular}} & 8.38 & 7.24 & 5.58 & 6.22 \\
\hline & \multicolumn{4}{|c|}{$\underline{\text { Stems }}$} \\
\hline Control (PK) & 25.21 & 29.93 & 2.58 & 2.42 \\
\hline $\mathbf{N}_{1}$ & 68.34 & 90.39 & 11.33 & 16.25 \\
\hline $\mathbf{N}_{2}$ & 108.20 & 103.30 & 25.36 & 21.22 \\
\hline Bio & 23.11 & 17.68 & 6.33 & 5.09 \\
\hline $1 / 2 N_{1}+$ Bio & 57.63 & 71.52 & 9.49 & 11.94 \\
\hline $\mathrm{N}_{1}+\mathrm{Bio}$ & 88.71 & 90.17 & 14.36 & 15.57 \\
\hline CM & 91.65 & 165.90 & 16.98 & 20.58 \\
\hline $1 / 2 \mathbf{C M}+\mathbf{B i o}$ & 155.50 & 251.30 & 27.54 & 34.90 \\
\hline \multirow[t]{2}{*}{\begin{tabular}{|l} 
LSD (0.05) \\
\end{tabular}} & 9.32 & 17.40 & 5.04 & 8.06 \\
\hline & \multicolumn{4}{|c|}{$\underline{\text { Roots }}$} \\
\hline Control (PK) & 13.25 & 10.36 & 1.75 & 2.95 \\
\hline $\mathbf{N}_{1}$ & 26.67 & 29.88 & 13.68 & 10.69 \\
\hline $\mathbf{N}_{2}$ & 48.81 & 56.37 & 14.27 & 17.75 \\
\hline Bio & 15.76 & 18.59 & 3.15 & 2.91 \\
\hline $1 / 2 N_{1}+$ Bio & 40.58 & 32.29 & 16.52 & 9.92 \\
\hline $\mathrm{N}_{1}+\mathrm{Bio}$ & 75.39 & 34.43 & 48.43 & 7.87 \\
\hline $\mathbf{C M}$ & 73.53 & 22.80 & 18.82 & 5.01 \\
\hline $1 / 2 \mathbf{C M}+\mathbf{B i o}$ & 59.19 & 32.12 & 11.64 & 6.42 \\
\hline LSD (0.05) & 11.05 & 5.09 & 6.61 & 7.69 \\
\hline
\end{tabular}

$\mathrm{N}_{1}$ or $\mathrm{N}_{2}=3$ or $6 \mathrm{~g}$ ammonium sulphate,

$\mathrm{CM}=$ Cattle manure,

Bio $=$ Bio-fertilization .

The data in Table 2, also show that replacing half of the chemical $\mathrm{N}$ fertilization rates with bio-fertilization had no advantage over using the whole rates of $\mathrm{N}$ without bio-fertilization. In fact, using bio-fertilization in combination with half of the chemical $\mathrm{N}$ rates instead of using the whole rates (i.e., $\mathrm{PK}+1 / 2 \mathrm{~N}_{1}+$ biofertilization instead of $\mathrm{PK}+\mathrm{N}_{1}$, or PK $+\mathrm{N}_{1}+$ bio-fertilization instead of $\mathrm{PK}+\mathrm{N}_{2}$ ) generally resulted in a decrease in the recorded values. 
In contrast, cattle manure $(\mathrm{CM})$ was more effective when half of the used rate was replaced with bio-fertilization, compared to using the whole $\mathrm{CM}$ rate without bio-fertilization. In fact, using PK $+1 / 2 \mathrm{CM}+$ bio-fertilization was more effective than any other fertilization treatment for increasing the fresh and dry weights of stems /plant (in both seasons).

\section{Fresh and dry weights of roots /plant}

The data presented in Table 2 show that, in general, the fresh and dry weight of roots was significantly increased by the different fertilization treatments. However, fertilization using PK + bio-fertilization (without chemical $\mathrm{N}$ fertilization or cattle manure) caused only slight (insignificant) increases in the values recorded in the first season, compared to the control. In the second season, the favourable effect of fertilization on roots fresh weight was more evident, with all of the tested treatments giving significant increases in the fresh weight of roots, compared to the control. On the other hand, only two treatments $\left(\mathrm{PK}+\mathrm{N}_{1}\right.$, or $\left.\mathrm{PK}+\mathrm{N}_{2}\right)$ significantly increased the dry weight of roots in the second season, while all other treatments had no significant effect on roots dry weight, compared to that of control plants.

Among the different fertilization treatments, using PK $+\mathrm{N}_{1}+$ bio-fertilization gave the highest roots fresh weight in both seasons, whereas the highest roots dry weight was obtained from plants fertilized using $\mathrm{PK}+\mathrm{N}_{2}$.

The above results are in agreement with the findings of Mohamed (2003) on periwinkle, and Sakr (2005) on Cassia acutifolia plants.

\section{Flowering}

\section{Number of flower stalks /plant}

The results recorded in the two seasons (Table 3) show that, in general, the number of flower stalks /plants was significantly increased by most of the tested fertilization treatments. The favourable effect of the different fertilization treatments on flower production is in agreement with the findings of Correa-Junior et al. (1999) on Chamomilla recutita plants, and Gouda (2002) on Tagetes erecta.

Among the different treatments tested, the most effective one was the application of $\mathrm{PK}+1 / 2 \mathrm{CM}+$ bio-fertilization. This treatment gave the highest value in the second season. In the first season, only one other treatment $\left(\mathrm{PK}+\mathrm{N}_{2}\right)$ gave a slightly higher value than that recorded on plants fertilized with $\mathrm{PK}+1 / 2 \mathrm{CM}+$ bio-fertilization.

\section{Stalk length}

It can be seen from the results recorded in the two seasons (Table 3) that in most cases, stalk length was increased by the different fertilization treatments, compared to the control.

It is also clear from the presented data that chemical $\mathrm{N}$ fertilization (especially at the higher rate) without bio-fertilization was more effective than organic fertilization for increasing stalk length. Replacing half of the chemical nitrogenous fertilization 
Table 3. Effect of chemical (NPK), organic and bio-fertilization on flowering characteristics in Amaranthus tricolor L. plants during the 2000 and 2001 seasons.

\begin{tabular}{|l|cc|cc|cc|cc|}
\hline \multirow{2}{*}{ Treatments } & \multicolumn{2}{|c|}{$\begin{array}{c}\text { Number of } \\
\text { flower stalks } \\
\text { /plant }\end{array}$} & \multicolumn{2}{|c|}{$\begin{array}{c}\text { Stalk length } \\
\text { (cm) }\end{array}$} & \multicolumn{2}{c|}{$\begin{array}{c}\text { Stalks fresh } \\
\text { weight } \\
\text { (g/plant) }\end{array}$} & \multicolumn{2}{c|}{$\begin{array}{c}\text { Stalks dry } \\
\text { weight } \\
\text { (g/plant) }\end{array}$} \\
\cline { 2 - 9 } & $\mathbf{2 0 0 0}$ & $\mathbf{2 0 0 1}$ & $\mathbf{2 0 0 0}$ & $\mathbf{2 0 0 1}$ & $\mathbf{2 0 0 0}$ & $\mathbf{2 0 0 1}$ & $\mathbf{2 0 0 0}$ & $\mathbf{2 0 0 1}$ \\
\hline Control (PK) & 1.33 & 1.58 & 20.19 & 24.22 & 6.70 & 10.60 & 2.16 & 2.15 \\
$\mathbf{N}_{\mathbf{1}}$ & 4.13 & 3.97 & 28.77 & 29.07 & 22.13 & 35.29 & 4.22 & 6.70 \\
$\mathbf{N}_{\mathbf{2}}$ & 6.25 & 3.83 & 32.78 & 33.08 & 39.91 & 30.48 & 7.07 & 5.34 \\
$\mathbf{B i o}$ & 2.33 & 2.33 & 26.09 & 15.50 & 17.12 & 12.85 & 2.60 & 2.36 \\
$\mathbf{1} / \mathbf{2} \mathbf{N}_{\mathbf{1}}+$ Bio & 4.17 & 3.67 & 26.70 & 27.39 & 37.55 & 23.83 & 7.27 & 5.58 \\
$\mathbf{N}_{\mathbf{1}}+\mathbf{B i o}$ & 4.83 & 4.33 & 29.31 & 27.69 & 34.55 & 29.09 & 6.13 & 5.10 \\
$\mathbf{C M}$ & 4.67 & 3.50 & 28.00 & 27.62 & 25.77 & 25.40 & 5.23 & 3.22 \\
$\mathbf{1} / \mathbf{C M}+\mathbf{B i o}$ & 6.22 & 4.50 & 25.13 & 29.19 & 26.89 & 33.03 & 4.46 & 3.04 \\
\hline LSD (0.05) & $\mathbf{2 . 1 5}$ & $\mathbf{2 . 2 0}$ & $\mathbf{6 . 1 4}$ & $\mathbf{4 . 8 0}$ & $\mathbf{8 . 9 1}$ & $\mathbf{1 1 . 2 3}$ & $\mathbf{1 . 6 1}$ & $\mathbf{1 . 6 9}$ \\
\hline
\end{tabular}

$\mathrm{N}_{1}$ or $\mathrm{N}_{2}=3$ or $6 \mathrm{~g}$ ammonium sulphate. $\mathrm{CM}=$ Cattle manure. Bio = Bio-fertilization.

rates, or half of the cattle manure $(\mathrm{CM})$ rate, with bio-fertilization was not beneficial in terms of giving significantly longer flower stalks.

Among the different fertilization treatments, the most effective one for increasing stalk length was application of $\mathrm{PK}+\mathrm{N}_{2}$, which gave the longest stalks in both seasons.

\section{Fresh and dry weights of flower stalks /plant}

The results recorded in the two seasons (Table 3) show that in both seasons, most of the fertilization treatments significantly increased the fresh and dry weights of flower stalks /plant. However, the relative effectiveness of the treatments (compared to each other) varied from one season to the other. In the first season, the three most effective treatments for increasing stalks fresh and dry weights/plant were those which included the high $\mathrm{N}$ fertilization rate, or bio-fertilization combined with half of the two $\mathrm{N}$ fertilization rates (viz., $\mathrm{PK}+\mathrm{N}_{2}, \mathrm{PK}+1 / 2 \mathrm{~N}_{1}+$ bio-fertilization and $\mathrm{PK}+\mathrm{N}_{1}+$ bio-fertilization), with no significant difference between these three treatments. Also, in the second season, the highest fresh and dry weights of stalks /plant were obtained with fertilization using $\mathrm{PK}+\mathrm{N}_{1}$. However, the second highest fresh weight of stalks /plant in the second season was obtained from plants fertilized using $\mathrm{PK}+1 / 2 \mathrm{CM}+$ bio-fertilization, while the second highest dry weight of stalks/plant was obtained from plants fertilized using $\mathrm{PK}+1 / 2 \mathrm{~N}_{1}+$ bio-fertilization. Fertilization with $\mathrm{PK}+\mathrm{N}_{2}$ gave the third highest values for fresh and dry weights in the second season. From the above results, it can be concluded that in most cases, chemical $\mathrm{N}$ fertilization (with or without bio-fertilization) was more effective than cattle manure for increasing the fresh and dry weights of flower stalks /plant.

The increase in the fresh and dry weights of flower stalks formed by plants receiving most of the fertilization treatments is in agreement with results reported by Hammam (1996) on anise (Pimpinella anisum). 


\section{Effect on chemical composition}

\section{Leaf pigments content}

\section{a. Chlorophyll ( $a, b$ and total chlorophylls) content}

Chemical analysis of fresh leaf samples (Table 4) has shown that in most cases, the different fertilization treatments increased the contents of chlorophyll "a", chlorophyll " $b$ " and total chlorophylls in leaves of Amaranthus tricolor. The general increase in the chlorophylly content as a result of applying the different fertilization treatments is in agreement with the findings of Mohamed (2003) on periwinkle, and Sakr (2005) on Cassia acutifolia.

Among the different treatments, fertilization with a combination of bio-fertilization and cattle manure (i.e., $\mathrm{PK}+1 / 2 \mathrm{CM}+$ bio-fertilization) gave the best results in terms of chlorophyll synthesis and accumulation in leaves. In both seasons, this treatment gave the highest chlorophyll "a" and total chlorophylls $(\mathrm{a}+\mathrm{b})$ contents. These results are in agreement with those reported by Sakr (2005) on Cassia acutifolia. On the other hand, the highest chlorophyll " $b$ " content recorded in the first season was obtained from plants fertilized with $\mathrm{PK}+\mathrm{N}_{1}$, whereas the highest chlorophyll " $\mathrm{b}$ " content in the second season was obtained from plants fertilized with $\mathrm{PK}+\mathrm{N}_{2}$.

\section{b. Carotenoids}

The data in (Table 4) show that in both seasons, the highest carotenoids content was found in the leaves of plants fertilized with a combination of biofertilization and organic manure (i.e., $\mathrm{PK}+1 / 2 \mathrm{CM}+$ biofertilization). This increase in the carotenoids content as a result of supplying the plant with a mixture of organic (cattle) manure and bio-fertilization is similar to that reported by Sakr (2005) on Cassia acutifolia. On the other hand, all the other treatments gave results that varied from one season to the other, since they decreased the recorded values in the first season, but increased them in the second season, compared to the control.

\section{c. Anthocyanin}

The anthocyanin content in leaves of Amaranthus tricolor was increased by the different fertilization treatments, compared to the control (Table 4). In both seasons, the highest anthocyanin content was obtained as a result of fertilization using $\mathrm{PK}+1 / 2 \mathrm{CM}+$ bio-fertilization, followed by $\mathrm{PK}+\mathrm{N}_{1}+$ bio-fertilization, then PK + $\mathrm{CM}$. On the other hand, the least effective treatment for increasing the anthocyanin content was the application of bio-fertilization without any chemical $\mathrm{N}$ fertilization or cattle manure (i.e. using PK + bio-fertilization).

From the above results, it is clear that, in general, using a combination of bio-fertilization and cattle manure (CM) was the most suitable treatment for increasing the content of the different leaf pigments (chlorophylls, carotenoids and anthocyanin). This may be explained by the fact that organic manures may result in acidity of the soil, leading to higher availability of the nutrients needed for anthocyanin synthesis. Also, decomposition of organic manure as a result of microorganism activity may result in the release of micronutrients into the soil, which are involved in the synthesis of pigments. 


\section{Total carbohydrates contents in leaves, stems, flowers and roots:}

The results of chemical analysis of the different plant parts (Table 5) show that in most cases, the total carbohydrates contents in the leaves, stems, flowers and roots were higher in plants receiving the different fertilization treatments than in the control plants. A generally favourable effect of different fertilization treatments on the carbohydrates content in plant tissues has also been observed by Gouda (2002) on Amaranthus tricolor, and Sakr (2005) on Cassia acutifolia.

Among the different treatments, fertilization with a combination of

biofertilization and cattle manure ( $\mathrm{PK}+1 / 2 \mathrm{CM}+$ bio-fertilization) gave the best results in terms of synthesis and accumulation of carbohydrates. In both seasons, this treatment gave the highest total carbohydrates contents in the roots and flowers. Also, this treatment gave the highest total carbohydrates contents in the leaves and stems in the second season. A promotion in the carbohydrates content in plants receiving mixtures of organic and bio-fertilization has also been reported by Sakr (2005) on Cassia acutifolia. On the other hand, in the first season, the highest total carbohydrates contents in the leaves and stems were obtained in plants fertilized using $\mathrm{PK}+\mathrm{N}_{1}+$ bio-fertilization).

Table (5): Effect of chemical (NPK), organic and bio-fertilization on the total carbohydrates $(\%$ D.W.) in the leaves, stems, flowers and roots of Amaranthus tricolor L. plants during the 2000 and 2001 seasons.

\begin{tabular}{|r|cc|cc|cc|cc|}
\hline \multirow{2}{*}{ Treatments } & \multicolumn{8}{|c|}{ Total carbohydrates percents } \\
\cline { 2 - 9 } & \multicolumn{2}{|c|}{ Leaves } & \multicolumn{2}{|c|}{ Stems } & \multicolumn{2}{c|}{ Roots } & \multicolumn{2}{c|}{ Flowers } \\
\cline { 2 - 9 } & $\mathbf{2 0 0 0}$ & $\mathbf{2 0 0 1}$ & $\mathbf{2 0 0 0}$ & $\mathbf{2 0 0 1}$ & $\mathbf{2 0 0 0}$ & $\mathbf{2 0 0 1}$ & $\mathbf{2 0 0 0}$ & $\mathbf{2 0 0 1}$ \\
\hline Control (PK) & 13.96 & 13.44 & 14.92 & 8.60 & 15.46 & 9.80 & 10.09 & 6.50 \\
$\mathbf{N}_{\mathbf{1}}$ & 16.14 & 15.77 & 16.24 & 10.31 & 17.47 & 11.01 & 15.10 & 11.20 \\
$\mathbf{N}_{\mathbf{2}}$ & 15.84 & 15.98 & 15.87 & 12.43 & 16.24 & 9.50 & 16.30 & 9.80 \\
$\mathbf{B i o}$ & 15.00 & 14.50 & 15.81 & 10.52 & 16.50 & 12.00 & 12.01 & 10.91 \\
$\mathbf{1} / \mathbf{2} \mathbf{N}_{\mathbf{1}}+\mathbf{B i o}$ & 15.77 & 17.33 & 16.24 & 11.08 & 17.15 & 15.50 & 15.00 & 12.30 \\
$\mathbf{N}_{\mathbf{1}}+\mathbf{B i o}$ & 19.10 & 19.50 & 16.33 & 13.69 & 18.01 & 11.22 & 15.66 & 11.91 \\
$\mathbf{C M}$ & 14.99 & 17.01 & 15.80 & 15.71 & 18.50 & 17.17 & 12.23 & 11.80 \\
$\mathbf{1} / \mathbf{C M}+\mathbf{B i o}$ & 16.54 & 20.00 & 15.98 & 18.01 & 24.66 & 22.01 & 17.05 & 13.01 \\
\hline
\end{tabular}

\section{Nutrient contents in leaves, stems, flowers and roots}

a. Nitrogen

The data presented in Table 6 show that in both seasons, fertilization of Amaranthus tricolor plants with $\mathrm{PK}+\mathrm{N}_{2}$ gave the highest $\mathrm{N}$ content in the leaves. The increase in the leaf $\mathrm{N}$ content as a result of chemical $\mathrm{N}$ fertilization is similar to that reported by Yadav et al. (1999) on Tagetes erecta. Also, this treatment $\left(\mathrm{PK}+\mathrm{N}_{2}\right)$ gave the highest $\mathrm{N}$ contents in the stems and flowers in the first season. On the other hand, the highest $\mathrm{N}$ content in the roots (in both seasons) was found in plants fertilized with $\mathrm{PK}+$ biofertilization. In the second season, the highest $\mathrm{N}$ content in the stems was obtained in plants fertilized using $\mathrm{PK}+\mathrm{CM}$, while the highest $\mathrm{N}$ 
Table 6. Effect of chemical (NPK), organic and bio-fertilization on the nitrogen, phosphorus and potassium (\% D.W.) in the leaves, stems, roots and flowers of Amaranthus tricolor $\mathbf{L}$. plants during the 2000and 2001 seasons.

\begin{tabular}{|c|c|c|c|c|c|c|}
\hline \multirow{2}{*}{ Treatments } & \multicolumn{2}{|c|}{ Nitrogen } & \multicolumn{2}{|c|}{ Phosphorus } & \multicolumn{2}{|c|}{ Potassium } \\
\hline & 2000 & 2001 & 2000 & 2001 & 2000 & 2001 \\
\hline & \multicolumn{6}{|c|}{ Leaves } \\
\hline $\begin{array}{l}\text { Control (PK) } \\
\mathrm{N}_{1} \\
\mathrm{~N}_{2} \\
\mathrm{Bio} \\
1 / 2 \mathrm{~N}_{1}+\mathrm{Bio} \\
\mathrm{N}_{1}+\mathrm{Bio} \\
\mathrm{CM} \\
1 / 2 \mathrm{CM}+\mathrm{Bio} \\
\end{array}$ & $\begin{array}{l}2.48 \\
1.96 \\
2.68 \\
1.88 \\
2.04 \\
2.20 \\
2.52 \\
2.44 \\
\end{array}$ & $\begin{array}{l}2.08 \\
2.16 \\
2.96 \\
2.28 \\
1.56 \\
2.08 \\
1.88 \\
2.16 \\
\end{array}$ & $\begin{array}{l}0.110 \\
0.090 \\
0.117 \\
0.085 \\
0.092 \\
0.098 \\
0.119 \\
0.115 \\
\end{array}$ & $\begin{array}{l}0.108 \\
0.110 \\
0.103 \\
0.080 \\
0.077 \\
0.104 \\
0.102 \\
0.105 \\
\end{array}$ & $\begin{array}{l}1.78 \\
1.14 \\
1.27 \\
1.48 \\
1.69 \\
1.37 \\
1.78 \\
1.52 \\
\end{array}$ & $\begin{array}{l}1.50 \\
1.01 \\
1.10 \\
1.75 \\
1.14 \\
2.52 \\
2.31 \\
2.26 \\
\end{array}$ \\
\hline $\begin{array}{l}\text { Control (PK) } \\
\mathbf{N}_{1} \\
\mathbf{N}_{2} \\
\text { Bio } \\
1 / 2 \mathbf{N}_{1}+\mathrm{Bio} \\
\mathrm{N}_{1}+\mathrm{Bio} \\
\mathrm{CM} \\
1 / 2 \mathrm{CM}+\mathrm{Bio} \\
\end{array}$ & $\begin{array}{l}1.09 \\
1.12 \\
1.66 \\
0.83 \\
0.94 \\
1.04 \\
0.62 \\
0.83 \\
\end{array}$ & $\begin{array}{l}1.35 \\
0.83 \\
1.14 \\
0.94 \\
1.04 \\
0.62 \\
1.87 \\
0.94 \\
\end{array}$ & $\begin{array}{l}\text { Ste } \\
0.062 \\
0.052 \\
0.078 \\
0.056 \\
0.090 \\
0.041 \\
0.051 \\
0.078 \\
\end{array}$ & $\begin{array}{l}0.077 \\
0.041 \\
0.077 \\
0.056 \\
0.042 \\
0.068 \\
0.044 \\
0.045 \\
\end{array}$ & $\begin{array}{l}2.23 \\
1.56 \\
1.80 \\
2.28 \\
1.92 \\
1.75 \\
1.99 \\
1.71 \\
\end{array}$ & $\begin{array}{l}1.23 \\
1.70 \\
1.65 \\
2.41 \\
1.71 \\
1.97 \\
2.05 \\
1.95 \\
\end{array}$ \\
\hline $\begin{array}{l}\text { Control (PK) } \\
\mathbf{N}_{1} \\
\mathbf{N}_{2} \\
\text { Bio } \\
1 / 2 \mathbf{N}_{1}+\mathrm{Bio} \\
\mathrm{N}_{1}+\mathrm{Bio} \\
\mathrm{CM} \\
1 / 2 \mathrm{CM}+\mathrm{Bio}\end{array}$ & $\begin{array}{l}0.88 \\
1.04 \\
1.08 \\
1.24 \\
0.64 \\
0.48 \\
0.60 \\
0.44 \\
\end{array}$ & $\begin{array}{l}0.72 \\
0.60 \\
0.64 \\
1.56 \\
1.12 \\
0.52 \\
0.64 \\
0.92 \\
\end{array}$ & $\begin{array}{l}\quad \text { Ro } \\
0.072 \\
0.063 \\
0.080 \\
0.054 \\
0.051 \\
0.054 \\
0.047 \\
0.046\end{array}$ & $\begin{array}{l}0.063 \\
0.058 \\
0.084 \\
0.080 \\
0.079 \\
0.059 \\
0.075 \\
0.071 \\
\end{array}$ & $\begin{array}{l}1.06 \\
1.35 \\
1.14 \\
2.16 \\
1.91 \\
1.61 \\
2.67 \\
1.80\end{array}$ & $\begin{array}{l}2.75 \\
2.58 \\
1.60 \\
2.84 \\
2.29 \\
2.20 \\
2.50 \\
1.68 \\
\end{array}$ \\
\hline $\begin{array}{l}\text { Control (PK) } \\
\mathbf{N}_{1} \\
\mathbf{N}_{2} \\
\text { Bio } \\
1 / 2 \mathbf{N}_{1}+\mathrm{Bio} \\
\mathrm{N}_{1}+\mathrm{Bio} \\
\mathrm{CM} \\
1 / 2 \mathrm{CM}+\mathrm{Bio}\end{array}$ & $\begin{array}{l}2.04 \\
1.15 \\
2.44 \\
2.20 \\
1.88 \\
1.28 \\
1.08 \\
1.16 \\
\end{array}$ & $\begin{array}{l}1.30 \\
1.40 \\
1.56 \\
1.72 \\
1.64 \\
1.00 \\
1.24 \\
1.72 \\
\end{array}$ & $\begin{array}{c}\text { Flov } \\
0.080 \\
0.098 \\
0.093 \\
0.095 \\
0.073 \\
0.067 \\
0.071 \\
0.084 \\
\end{array}$ & $\begin{array}{l}0.102 \\
0.111 \\
0.115 \\
0.116 \\
0.107 \\
0.084 \\
0.092 \\
0.087 \\
\end{array}$ & $\begin{array}{l}2.23 \\
1.45 \\
1.64 \\
1.45 \\
1.67 \\
1.57 \\
2.03 \\
1.79 \\
\end{array}$ & $\begin{array}{l}1.36 \\
1.15 \\
1.35 \\
1.44 \\
1.40 \\
1.86 \\
1.67 \\
1.57 \\
\end{array}$ \\
\hline
\end{tabular}

$\mathrm{N}_{1}$ or $\mathrm{N}_{2}=3$ or $6 \mathrm{~g}$ ammonium sulphate,

$\mathrm{CM}=$ Cattle manure,

Bio $=$ Bio-fertilization . 
content in the flowers was obtained when bio-fertilization was applied with or without organic manure (i.e., in plants fertilized with $\mathrm{PK}+$ bio-fertilization, or $\mathrm{PK}+1 / 2 \mathrm{CM}+$ bio-fertilization). In general, results recorded with the other fertilization treatments varied considerably from one season to the other, and from one part of the plant to the other.

\section{b. Phosphorus}

It can be concluded from the data in Table 6 that, in general, the phosphorus content in the different parts of Amaranthus tricolor plants showed no clear response to the different fertilization treatments. However, in some cases, chemical $\mathrm{N}$ fertilization, especially when used without bio-fertilization, appeared to have some favourable effect on the P content of the different plant parts. For example, fertilization of the plants with $\mathrm{PK}+\mathrm{N}_{2}$ gave the highest $\mathrm{P}$ content in the roots (in both seasons), and the highest $\mathrm{P}$ content in the stems in the second season. Also, fertilization using $\mathrm{PK}+\mathrm{N}_{1}$ gave the highest $\mathrm{P}$ content in leaves in the second season and the highest $\mathrm{P}$ content in flowers in the first season. The increase in the $\mathrm{P}$ content of plants receiving chemical $\mathrm{N}$ fertilization is in agreement with the findings of Yadav et al. (1999) on Tagetes erecta.

\section{c. Potassium}

The data presented in (Table 6) show that the effect of the tested fertilization treatments on the $\mathrm{K}$ content in different parts of the plant varied from one season to the other. In the first season, most of the treatments decreased the $\mathrm{K}$ contents of the leaves, stems and flowers, but increased the $\mathrm{K}$ content of the roots, compared to the control. In the second season, the $\mathrm{K}$ contents in the leaves and flowers were also decreased by fertilization using $\mathrm{PK}+\mathrm{N}_{1}$ or $\mathrm{PK}+\mathrm{N}_{2}$, but were increased by most of the other treatments, compared to those of control plants. The K content of the stems was increased by all the treatments in the second season, whereas the K content of the roots was decreased by most of treatments, compared to the control.

Among the different treatments, fertilization of the plants using $\mathrm{PK}+$ bio-fertilization appeared to be more effective than the other treatments for increasing the $\mathrm{K}$ contents in the stems and roots, as it gave the highest $\mathrm{K}$ content in the stems in both seasons, the highest $\mathrm{K}$ content in the roots in the second season, and the second highest $\mathrm{K}$ content in the roots in the first season (with $\mathrm{PK}+\mathrm{CM}$ giving the highest value).

Conclusively, from the above results, it is clear that chemical $\mathrm{N}$ fertilization is not necessary for the successful cultivation of Amaranthus tricolor, as the best results were obtained from plants fertilized with $\mathrm{PK}+1 / 2 \mathrm{CM}+$ bio-fertilization. This treatment gave the highest values for most of the growth and flowering characteristics, thus eliminating the need for chemical $\mathrm{N}$ fertilizers, and decreasing by half the rates of organic manure applied. In addition to optimizing plant growth, using a mixture of bio-fertilization and cattle manure also reduces the risks of chemical pollution to the aquifer. 


\section{REFERENCES}

Abdou, M.A. and A.A. El-Sayed (2002): Effect of planting date and bio-fertlization treatments on growth and yield characters of Carum carvi L. Proc. $2^{\text {nd }}$ Hort. Science Conference, 10-12 Sept., Kafr El-Sheikh, Tanta Univ., Egypt.

Cai, Y.; M. Sun; H. Wu; R. Huang and H. Corke (1998): Characterization and quantification of betacyanin pigments from diverse Amaranthus species. $J$. Agric. Food. Chem., 46 (6): 2063-2070.

Chandrikapure, K.R.; K.T. Sadawrte; D.M. Panchbhai and B.D. Shelke (1999). Effect of bioinoculants and graded doses of nitrogen on growth and flower yield of marigold (Tagetes erecta L.). Orissa Journal of Horticulture, 27(2): 31-34. (C.f. Hort. Abst., 69: 3376).

Chapman, H.D. and P.F. Pratt (1961): Methods of Soil, Plants and Water Analysis. Univ. of California, Division of Agricultural Sciences.

Correa-Junior, C.; P.D. Castellane and J. Jorge Neto (1999): Influence of organic and chemical fertilization on the yield of flowers, contents and composition of essential oil of Chamomilla recutita, L. (Rauschert). Acta Horticulturae, 502:195-201.

Dahiya, S.S.; N. Singh and S. Singh (1998). Effect of nitrogen and phosphorus on growth, flowering and yield of marigold (Tagetes erecta L.). Environment and Ecology, 16(4): 855-857. (C.f. Hort. Abst., 68: 6102).

Dubois, M.; F. Smith; K.A. Gilles; J.K. Hamilton and P.A. Rebers (1956). Colorimetric method for determination of sugars and related substances. Annal. Chem., 28 (3): 350-356.

Gouda, H.A.H. (2002): Physiological and biochemical studies on Tagetes erecta, L. and Amaranthus tricolor, L. plants as source of natural pigments. Ph.D. Thesis, Fac. Agric., Cairo Univ., Egypt.

Hafez, Y.A.M. (2003): Effect of sow spacings, nitrogenous and biofertilization treatments on growth, yield and chemical composition of Borago officinalis L. Ph.D. Thesis, Fac. Agric., Fayoum, Cairo Univ., Egypt.

Hammam, K.A. (1996): Effect of nitrogenous fertilization and irrigation on growth, yield and active constituents of anise plants (Pimpinella anisum, L.). M. Sc. Thesis, Fac. Agric., Cairo Univ., Egypt.

Hegazi, N.A.; M.A. Hamza; A. Othman; S. Ali; M.Z. Sedik and M. Fayez (1998): Modified combined carbon $\mathrm{N}$-deficient medium for isolation, enumeration and biomass production of diazotrophs. In Malik Kauser A., Mirza M. Sajjad, Ladha J.K., eds. Nitrogen Fixation with Non-Legumes. Kluwer Academic Publishers, Dordrecht, 247-253.

Hu, C.Y. (1959): Traditional Chinese remedy in prevention and treatment of diphtheria. Kiangsi J. Traditional Chinese Med. (Abst. In Chinese Med. J., 80, 194 (1):23-24.

Jackson, M.L. (1967): Soil Chemical Analysis. Prentice-Hall of India, pp. 144-197.

Lehmann, J.W. (1990): Pigments of grain and feral amaranth. Legacy, 3: 3-4. 
Mahfouz, S.A.S. (2003): Effect of biofertilization on growth and oil production of marjoram (Majorana hortensis Moench.) plant. Ph.D. Thesis, Fac. Agric., Cairo Univ., Egypt.

Marschner, H. (1999): Mineral Nutrition of Higher Plants. Academic Press, London.

Mohamed, M.A. (2003): Taxonomical and physiological studies on periwinkle plants. Ph.D. Thesis, Fac. Agric., Cairo Univ., Egypt.

Nawawi, M.; W.I. Santoso and S. Notodimejo (1986): The effect of shading and nitrogen fertilizer application on the yield of spinach (Amaranthus tricolor L.). Agrivita, 8/9 (1): 17-18. (C.f. Hort. Abst. 57: ......).

Paredes-Lopez, O. (1994): Amaranth Biology, Chemistry and Technology. CRC Press, Boca Raton, FL, USA, pp. 1-2, 155-160.

Piper, C.S. (1947): Soil and Plant Analysis. Univ. of Adelaide, Adelaide, Australia, pp. 258-275.

Pregl, F. (1945): Quantitative Organic Micro-Analysis. $4^{\text {th }}$ Ed., J. and A. Churchill, Ltd., London, pp. 78-85.

Sakr, W.R.A. (2005): Effect of organic and bio-fertilization on growth and active constituents production of senna plants. Ph.D. Thesis, Fac. Agric., Cairo Univ., Egypt.

Saric, M; R. Kastrori; R. Curic; T. Cupina and L. geric (1967): Chlorophyll determination. Univ. et M. Novon Sadu. Praktikum Iz Piziologiz Bilyaka Beograd Haucna Ajiga, p. 215.

Steel, R.C.D. and T.H. Torrie (1980): Principles and Procedures of Statistics. McGraw-Hill, New York,. 450 pp.

Yadav, P.K.; S. Singh and S.S. Dahiya (1999): Effect of N and FYM on chlorophyll and nutrient content in leaf of African marigold (Tagetes erecta L.) at flower bud initiation stage. Environment and Ecology, 17(1): 188-190. 


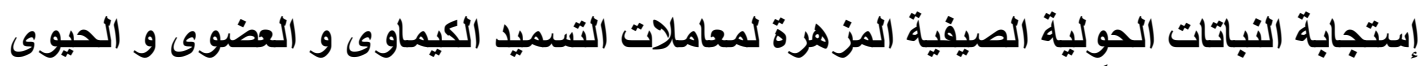
أولاً - نباتات الأمرنتس الهيف (Amaranthus tricolor L.)

عفت إسماعيل المعداوى

قسم بساتين الزينة، كلية الزراعة، جامعة القاهرة ، ج.م.ع.

أجريت هذه التجربة في مشتل تجارب قسم بساتين الزينة بكلية الزر اعة، جامعة القاهرة، الجيزة،

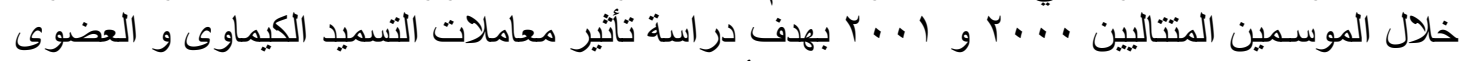

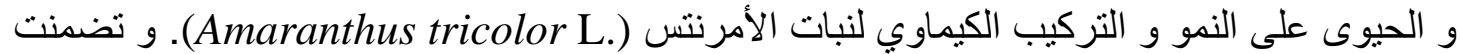

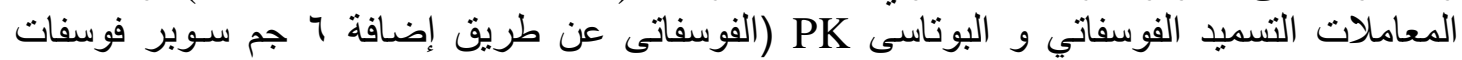

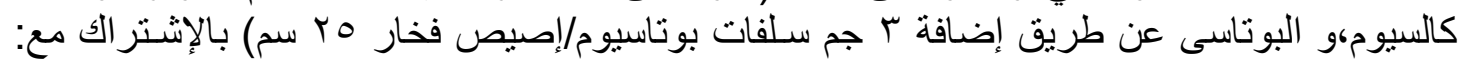

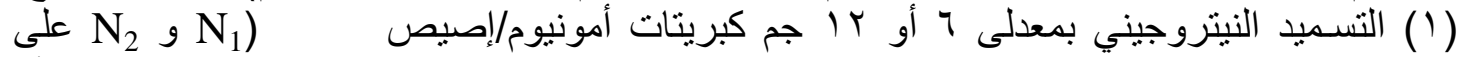

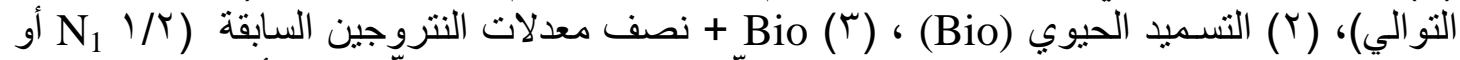

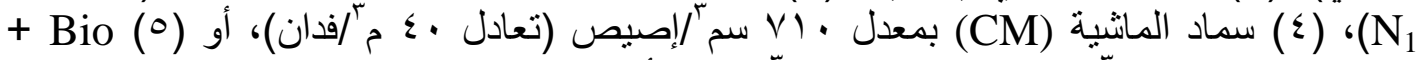

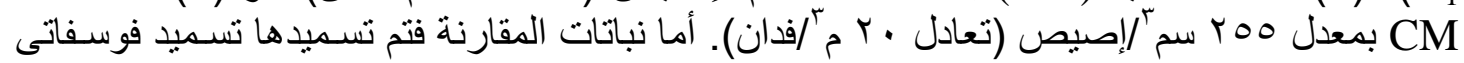

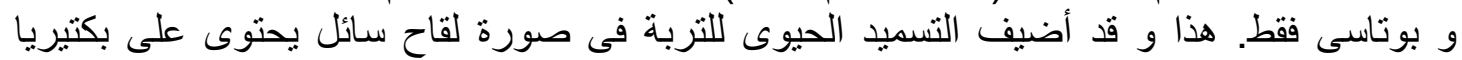
Pseudomonas و Klebsiella pneumonia و Azospirillum brasilense

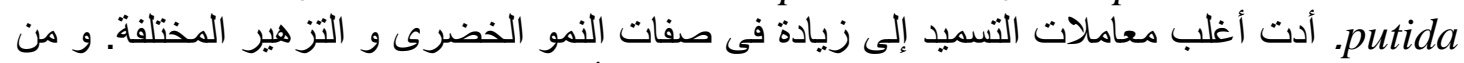

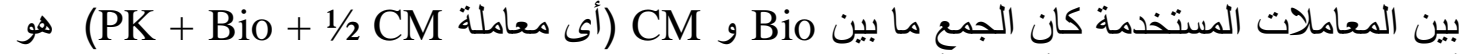

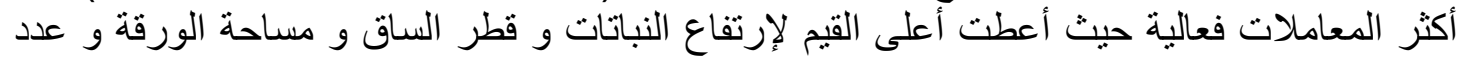

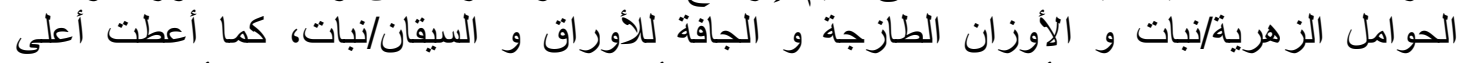

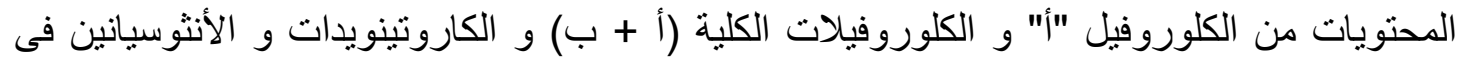

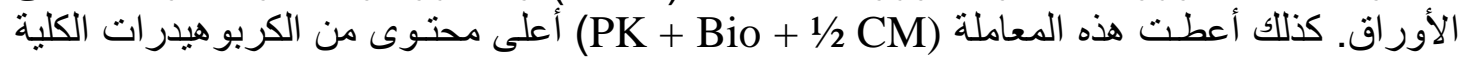

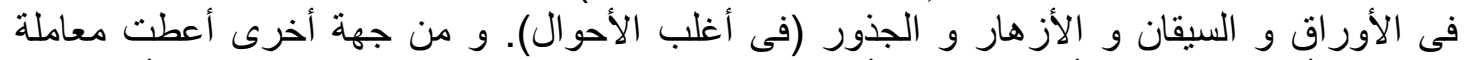

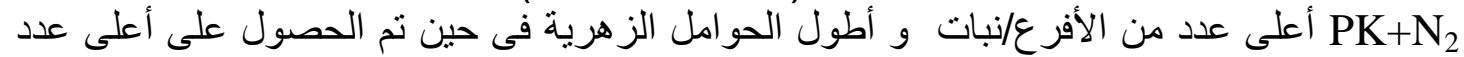

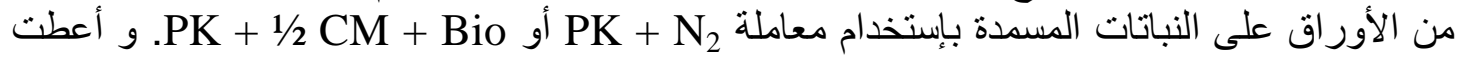

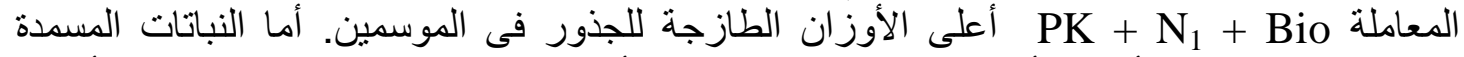
بإستخدام PK + N

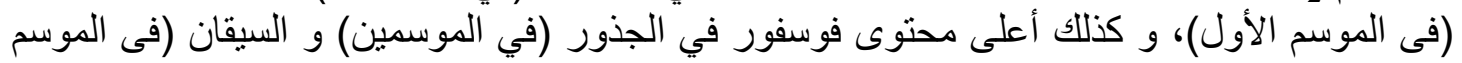

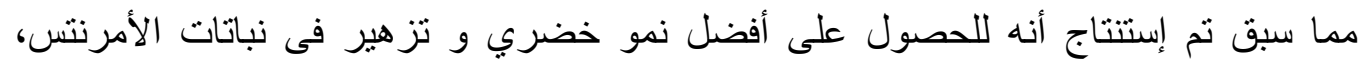

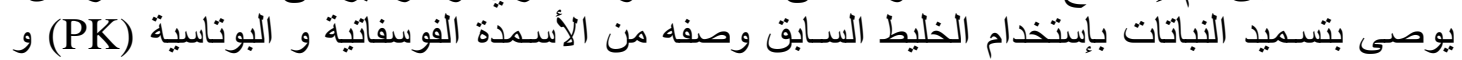
التسميد الحيوي و نصف المعدل الكامل من السماد العضوي (سماد الماثية). 